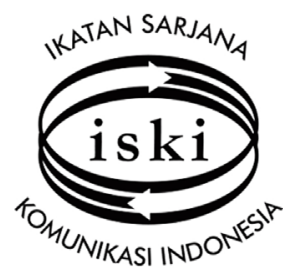

\title{
Gender Awareness of Maria Hartiningsih as Daily Kompas Reporter
}

\author{
http://dx.doi.org/10.25008/jkiski.v2i2.102 \\ Rajab Ritonga ${ }^{1}$, Endah Murwani ${ }^{2}$, Syafruddin Ritonga ${ }^{3}$ \\ ${ }^{1}$ Faculty of Communication, Universitas Prof. Dr. Moestopo (Beragama) \\ Jl. Hang Lekir I No. 8 Jakarta - Indonesia \\ ${ }^{2}$ Faculty of Communication, Universitas Multimedia Nusantara \\ Jl. Scientia Boulevard, Gading Serpong, Tangerang - Indonesia \\ ${ }^{3}$ Faculty of Communication, Universitas Medan Area, Jl. Kolam No. 1, Medan - Indonesia \\ ${ }^{1}$ rajab.ritonga@dsn.moestopo.ac.id; ${ }^{2}$ endahmurwani@umn.ac.id; ${ }^{3}$ syafruddin@uma.ac.id
}

\begin{abstract}
Structure of the media in Indonesia is still dominated by men who lack of gender sensitivity so that the role of women journalists as agents of change towards gender awareness is important to discuss. This study aims to determine the factors that make up the awareness, values and attitudes of women journalists on gender, and the influence of media and community structure in forming the gender awareness of women journalists. As a case study, a journalist of the largest newspaper in Indonesia, Kompas, namely Maria Hartiningsih is chosen. The study is based on the concept of genderedperspective journalism as a practice of journalistic that informs and questions inequality of the relationship between men and women. The study uses a qualitative approach with the method of Critical Discourse Analysis model of Norman Fairclough. Text analysis is conducted to examine the writings of Maria Hartiningsih in Kompas related to gender issues. The results show that at the textual level—since she started joining Kompas-Maria Hartiningsih's writing already highlighted problems of women, street children, and poverty. Her awareness and perspective on gender is a process conducted through the experience of reporting, discussions, and reading books related to gender. In the case of 'Maria', Kompas as an institution provides her with freedom to pour her thoughts.
\end{abstract}

Keywords: Women Journalists, Gender Awareness, Kompas Daily, Maria Hartiningsih.

\begin{abstract}
Abstrak
Struktur media di Indonesia masih didominasi laki-laki yang kurang memiliki sensitivitas gender sehingga peran jurnalis perempuan sebagai agen perubahan terkait kesadaran gender menjadi penting untuk didiskusikan. Penelitian ini bertujuan mengetahui faktor-faktor yang membentuk kesadaran, nilai-nilai dan sikap jurnalis perempuan tentang gender serta pengaruh struktur media dan masyarakat dalam membentuk kesadaran gender jurnalis perempuan. Sebagai kasus dipilih Maria Hartiningsih, wartawan harian Kompas. Metode penelitian menggunakan pendekatan kualitatif dengan metode analisis wacana kritis model Norman Fairclough. Analisis teks pada penelitian ini dilakukan untuk menganalisis tulisan-tulisan Maria Hartiningsih yang sudah dimuat di Harian Kompas yang berkaitan dengan persoalan gender. Hasil penelitian menunjukkan pada tataran teks - sejak awal bergabung dengan Kompas, Maria Hartiningsih sudah menyoroti masalah-masalah perempuan, anak jalanan dan kemiskinan. Kesadaran dan perspektifnya tentang gender merupakan suatu proses yang dilakukan melalui pengalaman liputan, diskusi, dan membaca buku-buku yang berkaitan dengan gender. Dalam kasus 'Maria', Kompas sebagai institusi memberikan kebebasan menuangkan pemikiran-pemikirannya.
\end{abstract}

Kata Kunci: Jurnalis Perempuan, Kesadaran Gender, Harian Kompas, Maria Hartiningsih 


\section{Introduction}

The implementation of gender-related policies in mass media newsroom is actually not new, yet it is always interesting to discuss mainly to study the unequal relationship between men and women in the practice of journalism that should have given impartial portions of coverage. In media news, there are commonly disparities of news related men and women, as demonstrated by the study conducted by Pratt et al (2008) on the 2004 Athens Olympics news. The study affirms that, in general, men are more reported than women. Even male athletes are more quoted in an article focusing on female athletes; whereas according to Kane, quoting Cunningham et al (2004),"the mass media have become one of the most powerful institutional forces for shaping values and attitutes in modern culture". Nevertheless, there are also media institutions that consciously implement a gender mainstreaming policy in their newsroom, as according to (Geertsema, 2009) have been conducted by Inter Press Service since 1994.

The importance of mass media's role in understanding gender for public is discussed by (Toffoletti, 2007) who questions: "how is gender-based violence covered in the sporting news?"

\section{[...] As the audience for sport news is primarily}

male, the way that sexual misconduct by footballers is reported in this section of the newspaper provides an important dimension in theorising how media institutions influence public discourse and understandings of gender.

Then, is the dominance of men over women in the news related to the more number of men working as a journalist than women? This study does not question the number, yet how is the involvement of women reporters in mass media in Indonesia related to gender awareness.

In Indonesia, there has been no official data so far, related to what is the actual number of women and men journalists. According to the Head of the Indonesian Journalists Association (PWI), Margiono, as quoted by Antara News Agency (Burhani, 2014) the number of Indonesian journalists (men and women) ranged from 100,000 to 150,000 people; while according to Viva.co.id news portal quoted the Head of the Indonesian Association of Independent Journalists (AJI), Suwarjono, (Wicaksono \& Haryanto, 2015), the number of Indonesian journalists is only about 40,000 people. Meanwhile the number of print media is 1,254 scattered throughout Indonesia (Agency, 2015) whose inhabitants are 254 million.

Based on the data from Institute for Press and Development Studies, an organization focusing on issues of mass media and culture in Indonesia, of the estimated 100,000 Indonesian journalists, 17 percent are women. Of that amount, according to Luviana (2012), only six percent of women journalists hold positions as decision makers in the newsroom, while 94 percent others work as a reporter without any position, thus only play the role and function of reportage.

A message is generated by a journalist. In that context, understanding the reporter becomes important to look at the substance of the generated news as stated by Cotter (2011): "Behind news stories are reporting, writing, and editing actions and decisions that constitute everyday practice within the news profession. As part of this, journalists are conscious of providing relevant coverage of the communities in which they work".

Although quantitatively there is an increase in female journalist profession, the involvement of women in the world of journalism and the media does not mean they have contributed a lot in determining the issues to be raised with a feminist perspective.

The composition factors gave birth to a genderbiased system of labor division. In this case there is actually a division of desk roles that reflects the private and the public roles with a clear dividing line. The desks of politics and economy in particular, and in some cases the desks of law, sports, and metro are considered to be more masculine; thus likened to have public role, since their position is believed to be a trendsetter and capable to control social change. These areas are usually headed by men. Meanwhile, the desks that take care of health, education, society, culture, and entertainment are considered feminine areas; hence commonly led by women-with the exception for education and culture that are often headed by men-and likened to have private role, considered 'not too sell' and therefore not productive. In fact these areas cannot be strictly separated from each other. The areas related to social and cultural issues are closely related to political and economic problems.

The problem is when women journalists are given a position to make a decision, would there be gendered-perspective news? Reality shows that even women journalists are often trapped in news and ar- 
ticle writing with significant gender bias or class bias.

Today, media in Indonesia, including women media seem to be too engrossed with the composition of women that they forget the main purpose of their work. Many journalists do not clearly comprehend the mission and goals of the writings when composing them. In fact, according to The Head of Indonesian Press Council, Yosep Adi Prasetyo (2016) (http:// politik.rmol.co/read/2016/04/16/243478/SudahkahMedia-Perempuan-Berperspektif-Dan-IdeologiGender-) a lot of women media, established with ideals for the advancement of women, turn out to be incapable of hindering the media capitalization that reinforces the subordination of women. The existing women media have not succeeded in establishing a discourse with gender perspective. The discourse raised by women media managed by and published to women tends to side more on patriarchal lines, and marginalize the gender roles of women. Women media, just like public media, even often practice discursive violence against women: the use of language, layout model, etc. that smacks of harassment.

The fact of the presence of women as leaders in the number of women media does not necessarily disconfirm the patriarchal line practiced by the media and managers' policies. Women media are also reluctant to penetrate the territory of political discourse. The editors of women media prefer to write about women activists for AIDS eradication, environmental activists, and the like, instead of to display a high-profile woman in political affairs.

Media actually need gender perspectives and views as a counterweight to their own perspectives in viewing political, social, economic and cultural problems that stand upon the patriarchal-structured nation building. In this case, media as the fourth estate play a significant role to strengthen it or else to diminish it, since the split personality of the media is rendered to issues of capital, the vision of investors, and professional workers in the field of press.

Gender sensitive journalism seems still far from expectations, because most journalists still lack of gender sensitivity in understanding the problems faced by women. Why is so? Because generally the women journalists are entering a truly masculine world of journalism in which the measures used the news are still the male ones, as the dominant party in the decision-making. The writings composed by women journalists have already been conditioned in male pattern. When there is a woman journalist who is concerned about gender sensitivity, she usually occupies less important positions within media organizations.

May Lan (2002) observes features showing that media have not had gender sensitivity, namely: (1) the news material about women presented in media remains featuring women as exploited objects; (2) women in the news are still portrayed as backward, without any authority; (3) the frequency of news related to women's issues is not continuous; (4) The issue of women gets small portions in the media.

However, such a change is not easy. There is a kind of worldview and culture of thinking that should be reformed in a large structure of editorship, largely male-dominated, and the demolition of patriarchal attitudes and personal ways among journalists, especially women journalists

A woman journalist appointed as the case for this study is Maria Hartiningsih, an editor in Kompas Daily. Why Maria Hartiningsih? Because Maria is one of the journalists who is seriously and consistently in favor of the weak, including for gender inequality. Her sidedness on issues of Human Rights in 2003 brought Maria to get Yap Thiem Hien award, in recognition of her writings in favor on issues of human rights, including the problems of children and women.

Accordingly, this study aims (1) to clarify the gender awareness represented in the writings of Maria Hartiningsih in Kompas; (2) study the factors that make up the awareness, values, and attitudes of Maria Hartiningsih as a woman journalist on gender, and (3) study the effect of the structure of the media and the public in shaping gender awareness of women journalists.

From the objectives of the study, this paper expects to give contribution to discuss (1) gender awareness through the writings of a woman journalist, Maria Hartiningsih, at Kompas Daily; (2) factors influencing the values and attitude of Maria Hartiningsih as a woman journalist on gender awareness; and (3) the effect of mass media structure on the Indonesian public in forming gender awareness of a woman journalist.

\section{Theoretical Framework}

Mass media is not believed to be a neutral body, and will always be in a tug of war between the different interests that are all rooted in economic and political interests. Golding and Murdock (Golding \& 
Murdock, 1997) said that the mass media is not believed to be a neutral body, they will always be in a tug of war between the different interests, all rooted in economic and political interest. In a capitalist society, mass media obtain a very high and strategic position; they strive for hegemony to obtain full freedom. Hence mass media will always be a contesting site of political and economic interests through the industrial and business mechanisms of relevant media that try to influence their agenda from time to time.

Shoemaker and Reese (1996) describe the tug of war between the various interests since the process of determining the news displayed by media through several steps: First, the individual level. At this level, journalists play a major role in determining the agenda of news: which news are broadcast, which are not, or which are edited. They are directly linked to the news sources and news events, and they can reconstruct the event to be aired in their respective media. In reconstructing an event or occurrence, journalists are influenced by their educational background, experience, reasoning, and to some extent subjective perception.

Second, the media routine level, i.e. the practices of the media in which decisions and perceptions regarding the event, brought by journalists to the news room, are influenced by the way the media professionals in the company they work organize their working system.

Third, the organizational level. At this level, organization as the structure of the media industry also determines the reconstruction process of events that occur.

Fourth, the external media level, the news reconstruction process is also determined by external factors such as the source of news, advertisement, customer, control of the government, market, and technology.

Fifth, ideological level with regard to the structure of power, in the sense of how far power, through the various rules it sets, is capable to influence the decision-making of the reconstruction process of the events in the news room.

This study is focused more on the individual level that influences media content. Some of the factors that determine the content of the media: (1) Characteristic, personal backgrounds (including ethnicity, education, gender and sexual orientation) and experiences; (2) Personal attitudes, values, and beliefs of media workers to the phenomenon, packaged in their media product, covering political attitudes, religious orientation, the values espoused in relation to individualism, modernism, altruistic democracy, leadership, ethnocentrism; (3) Professionalism, roles, and ethics owned by the mass media in managing human resources, including responsibility, ethics, objectivity, accuracy, mutual trust, and fair play.

Individuals as media workers will be affected by their values, beliefs, and attitudes. One of the dominant factors influencing the content of the media at the level of media institution policy is the background of gender in the individual level.

Generally journalists consider unnecessary to problematize the position of women in their factuality. Perhaps this is because the injustice taking place behind a fact has never been a concern of the journalists. In its work-operation they only have to depart from the technical standard of news worthiness. The technical standard, however, are placed in the principle of media commodification that basically put a journalist as a managerial employee.

Journalists consider facts to be a commodity of media information. In other words, the fact of women as a commodity in the public sphere is promoted as a media commodity, so that the media not only reflect but also replicate that fact. As replicators, media double the structural injustice, because the commodification of women lasted two stages: first when it becomes a social fact and second after it becomes a fact of media (information). This happens by making details of the facts in the mind frame of patriarchy. Commodification of media also emerges through the choice of words that reflect the mind frame of the media (journalists). Thus language is not representing the facts but representing the patriarchal nature of media mind.

Women struggles to get out of these injustices are embodied in various forms of resistance as well as received support from scientists publishing thoughts about women, and using feminist criticism in their theories. The presence of feminist theory in the middle of the social dynamics existing in the community gives birth to feminist movements that aim to fight such injustices.

Many feminist theories emphasize on the 'natural' oppression surrounding gender caused by the dominance of patriarchal ideology; feminism in many places is a study of the distribution of the power of sex. Feminist theory itself starts from an assumption that gender has spread in various aspects of life, 
where gender itself is a result of social construction which although useful, has been dominated by men specifically to oppress women.

Melin-Higgins and Djerf Pierre in Deborah Chambers, Linda Steiner and Carole Fleming (2004) said that, in dealing with sexism in the newsroom women commonly do one of the following three actions: (1) incorporation: women journalists are trying to be part of the men by adopting masculine values and attitudes, including a tendency to show objectivity; (2) feminist action: women journalists consciously and deliberately choose to produce coverage of the writing style different from the others, such as writing sexual violence and torture against children; (3) retreat: women journalists decide to work freelance or work from home to avoid the problem in the workplace.

The use of gender perspective in journalistic texts is based on the feminist awareness of journalist concerned. Feminist awareness is defined as an awareness of the oppression and exploitation of women in society, workplace, and the family as well as a conscious action by women or men to change such conditions. On the contrary, journalism is considered gender bias when the news about women uses the language and display representations of women that are stereotyping and degrading.

According to Subono (2005), there are two approaches in journalism, namely: neutral or objective, and gendered perspective. Neutral or objective approach is classified into mainstream journalism or general rules that must be applied. With this approach the writing is free of gender perspective. Meanwhile, journalism with a gender perspective is when the writing is written with sensitivity to gender.

\section{Material and Methodology}

The approach used in this study is a qualitative approach, especially to provide an overview of the process of gender awareness formation of female journalist, Maria Hartiningsih. The study is conducted by looking at the context of the problem as a whole with a focus on the 'process' instead on 'results'. Through this qualitative approach, this study is expected to bring understanding of the various aspects studied, among others, the factors that influence the formation of gender awareness on a woman journalist-in this case Maria Hartiningsih.

This study will use a method of Critical Discourse Analysis (CDA). CDA method attempts to link the text with the larger context. The larger context is outside the text, namely the socio-cultural-economic conditions considered to have power to construct reality, i.e. in this case the reality of gender awareness. Of the various existing methods of critical discourse analysis approach, we choose the analysis model of Norman Fairclough (Critical Discourse Analysis) since it is considered capable to answer the study questions, focusing to reveal the process of gender practices and uncover the ideological values operating in the media.

Text analysis in this study is on the writings of Mary Hartiningsih already published in Kompas, related to gender issues. The data obtained from the text analysis will provide an overview of the representation of Maria Hartiningsih's gender awareness at a micro level. Meanwhile at the meso level, the data are collected through in-depth interviews aiming at exploring the factors that influence the formation of gender awareness which will be reflected in the writings of Maria Hartiningsih.

\section{Result and Discussion}

\section{- The Figure of Maria Hartiningsih}

Maria Margaretha Hartiningsih is a woman journalist at Kompas daily, a newspaper with the largest circulation in Indonesia, an average of 530,000 copies per day with total reader more than two million people per day in all parts of Indonesia ("SEJARAH KOMPAS," n.d.) She began her career as a reporter in 1984 after graduating from College of Publication in Jakarta. Actually, being a reporter is not her first job; after graduating from Pharmacy Vocational School, she worked in a company not related to the media.

As a journalist, Maria is consistently productive, writing news and columns related to gender issues, poverty, human rights, violence against women, and pluralism. Her understanding is more complete after she completed a graduate study at the University of Indonesia on Women's Study. Her previous interest in gender issues was blossoming after attending some training as well as international conferences on women's issues.

Not only limited to covering and writing news, Maria also truly worked as a volunteer at the Home for the Dying and Destitute led by Mother Theresa, in Calcutta, India in the early 1990s. Her spiritual experience in Calcutta along with another woman journalist from Kompas, Myrna Ratna, was then written as a work of journalism in Kompas, which clearly 
shows her sidedness to the underprivileged.

In 2003 Maria became the first journalist to receive the Ya Thiam Hien award, a prestigious award in Indonesia, reserved for a public figure for her dedication to fight for human rights problems in Indonesia.

Maria's journalistic work can be traced in the Kompas daily that specifically provide special sheet of tabloid size as its supplement, under the name "Swara" since 1999. The sheets were entirely of women's issues. For one year "Swara" was circulated as part of the Kompas daily; yet due to the failure of getting the ad, it was removed as a supplement and "Swara" became a section on Kompas every Monday-initially two pages, then reduced to a single page, later to half a page, before eventually completely disappeared the following year (Luviana, 2012; Sunarto, 2007).

"Swara" was removed from Kompas daily for its failure to get ads. However, although there is a no longer "Swara" sheet or section that had firmly been the place for her and her friends' writings, it does not mean they no longer write any gender issues. Maria continues to write in Kompas daily to the present and her news are spread in the pages of Kompas.

\section{- The Writings of Maria Hartiningsih on Gender}

The works of Maria Hartiningsih is actually characterized as development journalism. She invites the readers to understand the problems of gender, injustice, human rights by clearly presenting them in Kompas daily.

Most of Maria Hartiningsih's writings are features and investigative reporting. Since joining Kompas, although her writings vary, Maria's concerns for issues of poverty, street children, and women have started to emerge. Her writings do not merely disclose data or facts, but also with a clear standing point clear, in favor of the weak.

In 1990s-after returning from Calcutta, India to volunteer at the Home for the Dying and Destitute where Mother Teresa devoted herself-Maria's writings focused more on Indonesian women and Indonesian female labor, working abroad as an uneducated laborer.

Analyzing the writings of Maria until the mid1990s, it appears that her interest and concern for women's issues are quite significant. Gender awareness, however, still has not appeared in her writings. She only raised issues such as women in prostitution, violence against women in the household, female labor, rape, sexual harassment, and others. Maria admitted to have not understood about gender and feminist theories.

In 1995 after Maria Hartiningsih followed the World Women's Conference in Beijing, her gender awareness has begun to emerge through her article entitled "Equality Equals to Liberation". Her gender awareness was increasingly formed after in 1997-1998 Maria was assigned to the United States as a correspondent, during which she began to learn about gender and feminist theories. On her return from the US, she was assigned to cover gender issues.

At that time, in May 1998, racial riots occurred with massive rape against Chinese ethnic in Jakarta. In 1999 Maria formally explored gender issues by continuing her study at the Department of Women's Studies at the Graduate Program, University of Indonesia. After that Maria extensively wrote about emancipation, gender, human rights, women's empowerment, and the like.

Some of the major papers written with a gender perspective are: (1) The article dated 24 April 1996 entitled "The Problem of Women Is Not Only Legislation, But Especially the Structure and Culture" highlights the discrimination against women particularly those due to the structure and culture. The struggle of women to achieve equality is incessant struggles, because what is encountered is the structure and culture that greatly affects the alteration of people's attitudes (including women) on the position and role of women; (2) The article dated 20 April 1997 entitled "The Fight Has Just Actually Started" frames that women struggle to achieve equality has just started with the emergence of new organizations, discussion groups, networks, NGOs, and individuals reacting to the status and role of women over the years. In her writing, Maria tells about the "sweet", "patient" journey of the women's organization during the New Order era that "did not ask many questions and with no criticism" as well "full of manners" with the work programs that actually domesticate women; (4) The article dated 3 August 1998 entitled "Keep Fighting for Justice for Women in the Workplace" insists that discrimination based on gender in workplaces is still ongoing;

(5) The article dated 20 December 1998, related to Mother's Day, entitled “The New Dawn of the Mother Movements" discuss the dynamics of women's movement with the speakers of some women activists and feminist, framed by Maria as a new dawn in the 
women's movement marking a positive development that will characterize the struggle of women in the future; (6) The article dated 5 January 1999, related to the riots in Jakarta, entitled "Ideology and Political Motivation in the History of Rape" frames that rapes in war and riots have ideologies and political motivations. In his writings Maria highlights women who have been the object of rape in armed conflict and violence, not only because they are considered the "property" of the enemy or the targeted outlet for hatred, but mainly because they are women who are considered enemies; (7) The article dated 18 April 1999 entitled "The Face of Kartini is not an Obsolete Portrait" frames that the phenomenon of the rise of women's movement should have been capable to unite solidarity and continue the ideals of Kartini who would not be suppressed;

(8) The article dated 21 May 2001 entitled "We are All Born by a Mother" highlights the need for awareness of women's health so that we can minimize the deaths of women in childbirth; (9) The article dated 17 June 2002 entitled "The Myths Advocating against Women" in essence frames the myths on chastity or virginity that advocate against women resulting in unpreparedness of Indonesians to accept a woman pregnant outside of marriage, while women are not prepared with the stigma inflicted by people to themselves; (10) The article dated 9 August 2004 entitled "Dismantling a World without a Husband" frames the life of widows without husbands, constructed and labeled negatively by society. Maria wrote how people never want to see a variety of factors and conditions causing women to be widowed; people tend to judge and give a bad label cruelly to widows, and (11) The article dated 11 February 2006 entitled "The Girls Stolen by Tradition" tells about traditions that imprison and oppress women. Women's values are determined by the "price" of the girl's dowry. At the end of his writing Maria encourages the reader to be willing to help girls who are locked in such traditions.

\section{- The Process of Maria Hartiningsih's Gender Awareness}

Relatively impoverished, Maria's childhood seems to influence her interest in poverty, even though she acknowledged that her past experience is not completely dominant. Over time the interest is more visible. "My interest is primarily on poverty. When told to report on housing, the point of my attention is on urban poor housing, housing for the poor in the city" she said. Her perspectives on poverty is so growing that she does not only see poverty as something black and white, and perceives it merely materially.

Maria loved the world of children that she reflects by write on violence against children, including sexual violence and child trafficking. Not only children are her focus of attention but also those who are marginalized. She not only pours her sidedness in writing, but also directly involves, volunteering at The Home for the Dying, Calcutta, where Mother Theresa had served. She also likes to visit various orphanages for disabled children, and visiting places of the marginalized in various slums. Maria also has solidarity with the marginalized in a certain sense, such as those exposed to HIV, gay, and lesbian. Her sidedness on the group is because they are also human beings who should not been excluded on moral grounds.

The writings of Maria continuously voicing her sidedness on those marginalized are delivered as it is. She does not only criticize, but also always provides inputs based on the knowledge she has; thus no wonder if she has thousands of books to support her profession as a journalist.

Her gender awareness and perspective, according to Maria herself, is a process. "Everything is a process, I used to be very feminist, but then now become mild" said Maria. Her attention to the problem of women has actually begun when she first worked in Kompas, whose idea has more to do with poverty. Although since 1984 Maria has highlighted on women, especially because at that time the problem of Indonesian Women Labor was rampant, Maria admitted not to understand about gender or feminist theories. She only raised issues of women, such as women in prostitution, violence against women in the household, rape, sexual harassment, etc.

In the 1990s when gender issues began to be talked about, activists had invited her to learn about gender; however Maria was still not familiar with feminist issues. Her gender awareness was formed after she was assigned to the United States as a correspondent in 1997-1998. During her stay in the US she began to learn more about gender and feminist theories. On her return from the US, she was assigned to cover gender issues. At that time, racial riots, the May 1998 event, coincidently occurred, leading to the fall of President Suharto's regime. In that event in addition to the burning and looting also occurred rapes against Chinese ethnic women.

In 1999 Maria formally explores gender by con- 
tinuing her studies on the Department of Women Studies at the Graduate Program of University of Indonesia. On May 6, 1999 Maria was invited by Ninuk Mardiana Pambudi to manage the supplement of Kompas, "Swara" that highlights gender issues, especially the inequality of women's roles. Nevertheless due to its incapability to bring in advertising, in mid-2001, Swara became a regular feature in Kompas on every Monday. According to Maria, at the time Swara was underestimated by fellow editors. This shows that Kompas journalists still did not have gender consciousness. Later the feature of Swara was also removed from Kompas page.

Her approach to gender issue is really based on her commitment to the profession of journalist. As a journalist who should cover gender issues, Maria sought to learn about it. "Because if I do not learn gender issues and get into it, then I might only be used by those activists". Maria's statement shows that as a journalist, she must understand the issues she covers, so that she could selectively citing sources. Therefore, Maria is notably critical of those who pretend to defend women yet have patriarchal bias. They talked about gender only as 'sales', in fact they do not understand gender.

Her perspectives on gender no longer refers to the grand theory of the four schools of feminism-radical, liberal, socialist and Marxist-but already multicultural and humanist. Therefore Maria's perspective on gender is not merely of women's struggles to play double roles, but actually makes both (women and men) to be human. Maria even reminds us that "Feminism is not something to be feared, because it is an attempt of democracy in the true sense, namely justice to humanize men and women who have the same responsibilities.

Further Maria explains that although biologically different-women can give birth, must have menstruation, and can breastfeed a child-both men and women are in charge of caring for the child. Thus, women's reproductive role is actually balanced with men's productive role. Hence, we see the value that is, instead of a polarization, a dialogue between men and women.

For Maria, putting the gender issue is not as easy as opposing the method of violence with another violence, since, in fact, the entire struggles to achieve gender equality and justice must be done by rejecting violence. And it comes to diction; not only the syntax, but also in the language. Maria exemplifies another word for 'rape' still often used by journalists, namely 'molest', 'harass', 'tarnish', 'take away virginity'. These words clearly reduce the action of rapping that destroy the entire life of the victims. 'Molest' also gives the connotation that the victim just accept the action, not fight; whereas in such news it is clear that the victims fight back. For Maria the use of such dictions for the word 'rape' is not only wrong, but it is also bad journalism. Similarly, the word 'sex worker' is still controversial. The use of the word 'sex worker' is considered by Maria inappropriate because it gives a connotation that the 'work' is similar with other jobs competed in the job market. According to Maria, no one wants to work in the area of sex.

Attention to women without a gender perspective can give birth to exploitation for economic purposes (commodification) of the media; thus making gendered perspective journalism not just raising the issue of women in quantity. If merely raising the issue of women, according to Maria, it is not a gendered perspective, but the exploitation of women. The writings of Maria are essentially a result of the dialogue of herself with various elements such as inner experience, books, knowledge, and interactions with various humans.

\section{- The Attitude of Kompas toward Maria's Concept on Gender}

Maria stated that Kompas is a highly patriarchal institution. "The thoughts of those sitting in the organizational structure are still very patriarchal". Maria gave examples of editorials related to the Mother's Day with the title "Mother is the skipper for the family and the nation." The editorial in Kompas gives glorifying expressions, and assumes it is women who are responsible for the family. This reflects a gender bias and patriarchal thought.

The tug of war between the various interests that are all rooted in the political and economic interests, as stated by Murdock and Golding, as well as Shoemaker and Resee, also occurrs at Kompas. The decisions to package the products are often based on the interests of capital. Maria gave examples of how she and Ninuk Pambudi struggled to publish tabloid Swara. "At first many opposed, but Ninuk continued to convince and fight them in the meeting" said Maria. Regarding the content, although it highlighted the inequality of women's roles, it is still mild on demand of the institution.

In 2000-one year after published-Swara as a 
tabloid supplement was eventually discontinued; the reason of which did not make money (advertising). This case shows that in a capitalist society, the mass media managers work with a strategy based on economic supporting capacity. In the case of Swara, the media function more prominently as a business institution. The institutional function as a media business is basically a dialectic between the realm of funding, as the main factor considered moving the production process, and the realm of marketing.

Although still highly patriarchal, Kompas is considered by Maria still democratic in some sense, in that Kompas gives her freedom to pour her thoughts. According to Maria, Kompas as an institution does not at all direct what she will write. Maria pointed out, once Kompas editorial wrote about pro-capital punishment, while the next day Maria wrote about contra-capital punishment. "They were okay; even the highest structure does not forbid us to write anything. That democracy, I said" said Maria.

Maria has an obsession that her journalist friends have a gender perspective. For that she continues to eliminate violence against women in the news in Kompas. According to her this is not easy because it involves the overhaul of the culture and mindset of journalists and editors. So far Maria strives to speak persuasively with friends for the elimination of violence against women in news and feature writing, without using feminist jargons that would certainly be hard to receive. Maria then put another weapon, i.e. the codes of journalism.

\section{Conclusion}

This section presents the conclusion obtained in this study. At the textual level, the writings of Maria Hartiningsih since she started joining Kompas until mid-1990s have already highlighted the problems of women, street children, and poverty. Nevertheless, at that time writings were still without a gender perspective. Maria's Gender awareness began to take shape after she became a volunteer in Calcutta, followed the International Women's Conference, studied in the US and took a summer course in the UK, as well as took a graduate program at the University of Indonesia.

At the discourse practice level, Maria Hartiningsih is a figure of journalist who is serious, responsible and consistent. Her inner experience background (like the socio-economic background of her parents) is recognized to affect the formation of her attitudes that always favor the poverty. Her awareness and per- spective on gender is a process undergone through the experience of reporting, discussions, and reading books related to gender.

Individual factors do not directly affect the media content. It is also influenced by the media routine, organizations, extra, and ideology. In the case of 'Maria', however, Kompas as an institution proves to give her freedom to pour her thoughts.

Gender perspectives and views are actually needed by media as a counterweight to their own perspectives in viewing the political, social, economic, and cultural problems that stand on the state building with patriarchal structure.

How, then, women journalists and media managers can apply a gender perspective in policy making and packaging its media content? The following points are expected to be considered by media policy makers to raise gender awareness of its journalists: (1) foster empathy and journalists who are pro-justice and gender equality through the journalism of empathy; and (2) include journalists in trainings on gender. It is intended to foster gender sensitivity and perspectives of the journalists.

References

Agency, A. N. (2015). Country Report Antara News Agency. Retrieved from http://www.oananews.org/ content/info/country-report-antara-news-agencyindonesia-oana-summit-congress-april-21-24-seulsouth

Burhani, R. (2014). Lebih 100000 Wartawan Belum Uji Kompetensi. Retrieved from http://www. antaranews.com/berita/449767/lebih-100000wartawan-belum-uji-kompetensi

Chambers, D., Steiner, L., \& Fleming, C. (2004). Women and Journalism. Psychology Press.

Cotter, C. (2011). Diversity Awareness and The Role of Language in Cultural Representations in News Stories. Journal of Pragmatics, 43(7), 1890-1899.

Cunningham, G. B., Sagas, M., Sartore, M. L., Amsden, M. L., \& Schellhase, A. (2004). Gender Representation in the NCAA News: Is the Glass Half Full or Half Empty? Sex Roles, 50(11), 861-870.

Geertsema, M. (2009). Gender Mainstreaming in International News: A Case Study of the Inter Press Service. Journalism \& Mass Communication Quarterly, 86(1), 65-84.

Golding, P., \& Murdock, G. (1997). The Political Economy of the Media. Edward Elgar Publishing. Lan, M. (2002). Pers, Negara dan Perempuan: Refleksi 
atas Praktik Jurnalisme Gender pada Masa Orde Baru. Yogyakarta: Kalika.

Luviana. (2012). Jejak Jurnalis Perempuan: Pemetaan Kondisi Kerja Jurnalis Perempuan di Indonesia. (M. Amiruddin, Ed.). Retrieved from https://books. google.co.id/books?id=7qH5oQEACAAJ

Pratt, J., Grappendorf, K., Grundvig, A., \& LeBlanc, G. (2008). Gender Differences in Print Media Coverage of the 2004 Summer Olympics in Athens, Greece. Women in Sport and Physical Activity Journal, 17(2), 34-41.

Sejarah Kompas. (n.d.). Retrieved from http://www. kgvaluecard.com/card/kompas/about-us/kompas.

Shoemaker Pamela, J., \& Reese Stephen, D. (1996). Mediating the Message. Theories of Influences on Mass Media Content 2nd ed. Longman.

Subono, N. I. (2005). Negara dan Kekerasan terhadap Perempuan. Yayasan Jurnal Perempuan.

Sunarto. (2007). Kekerasan Televisi terhadap Wanita: Studi Strukturasi Gender Industri Televisi dalam Naturalisasi Kekerasan terhadap Wanita melalui Program Televisi untuk Anak-anak. Disertasi, Universitas Indonesia.

Toffoletti, K. (2007). How is Gender-based Volence Covered in the Sporting news? An Account of the Australian Football League Sex Scandal. In Women's Studies International Forum (Vol. 30, pp. 427-438).

Victoria, W. (2016). Masih Banyak Media Perempuan Miskin Perspektif Gender. Retrieved from http://politik.rmol.co/read/2016/04/16/243478/ Sudahkah-Media-Perempuan-Berperspektif-DanIdeologi-Gender-

Wicaksono, B. A., \& Haryanto, A. T. (2015). Hanya Ada 40 Ribu Wartawan di Indonesia. Retrieved from http://www.viva.co.id/berita/nasional/670030hanya-ada-40-ribu-wartawan-di-indonesia 